\title{
SEMIOTIC APPROACH TO THE INTEPRETATION OF THE NOVEL PRIDE AND PREJUDICE BY JANE AUSTEN
}

\author{
Smagliy V. M.
}

\section{INTRODUCTION}

Jane Austen is a famous English novelist. She was born in 1775 in Hampshire country and died in 1816. It's an interesting fact that the cause of her death stays unknown. She came from a large family. His father was the priest of the Anglican Church. Nevertheless, Austen's family, consisting of four brothers and two sisters, didn't have a high standard of living or income.

Jane, along with her only sister, started learning at the age of eight in Oxford - under the direction of Ann Cawley. Sometime later, they moved to Southampton, where they both got typhus. That disease almost killed Jane. Before going to boarding school, Jane learned at home in the company of her sister. Financial problems of Austen's family made sisters stopped learning.

Jane tried to catch up on education by learning from books borrowed from older brother or her father. Mostly, she was reading novels. This made that she decided to try her ability at literary. Although her first work was primarily for use of only family members at first, she managed to create Love and Friendship. It is possible that she wrote it when she was fourteen. It was a novel that ridiculed the conventions of contemporary novels of romance. For sure it determined the style of future works of Jane Austen.

Her distinctive literary style relies on a combination of parody, burlesque, irony, free indirect speech and a degree of realism. She uses parody and burlesque for comic effect and to critique the portrayal of women in 18th-century sentimental and gothic novels.

Austen extends her critique by highlighting social hypocrisy through irony; she often creates an ironic tone through free indirect speech in which the thoughts and words of the characters mix with the voice of the narrator. The degree to which critics believe Austen's characters have psychological depth informs their views regarding her realism.

While some scholars argue that Austen falls into a tradition of realism because of her finely executed portrayal of individual characters and her emphasis on "the everyday", others contend that her characters lack a depth of feeling compared with earlier works, and that this, combined with Austen's polemical tone, places her outside the realist tradition. 
It is safe to conclude that Jane Austen has achieved a huge success. Her works are known throughout whole world. Her novels have been translated into many languages, so that they can get to a wider range of readers. These translations made Jane Austen's work known almost all over the world and even today it is hard to find people who had never heard about Austen's existence or one of hers more famous novels.

\section{General genre characteristics of the novel "Pride and Prejudice" by Jane Austen}

Jane, entering adulthood, continued to live in her family house. Nevertheless, around the year 1795 she managed to complete her work on the novel Lady Susan, one of the most valuable in her career. In 1811 she completed the novel Thoughtful and Romantic, in the meantime creating the first drafts of Pride and Prejudice as well as Northanger Abbey. Her plots are fundamentally about education; her heroines come to see themselves and their conduct more clearly, and become better, more moral people. While Austen steers clear of the formal moralizing common in early-19th-century literature, morality-characterized by manners, duty to society and religious seriousness-is a central theme of her works.

At that time, Austen's family moved to Bath, where George Austen Jane's father - died five years later. Shortly thereafter, Jane and her mother moved to Southampton, where they led a decent and peaceful life - of course, until the next move. In 1809 both women moved to Hampshire. It was the place where Jane finally started publishing her novels - though not under her own name. The first novels signed by the name of Jane Austen took place only after her death.

Seeing the above description, it can be assumed that Jane has stayed with her mother for the rest of her life. This is due to the fact that Jane has never got married. Although it is possible to find information about her numerous affairs, none of men present in her life has become her husband. It is suggested that Jane discarded any marriage proposals received from them.

'Jane Austen (1775-1817) led a peaceful and monotonous life in the countrywide - on the estate of her brother - or in the towns of south England - Hampshire and Bath. And yet, she proved to be an unparalleled observer of human characters and customs. Daughter of the village pastor, she loved eighteenth-century literature and motto of nascent Romanticism was foreign to her.' 1

\footnotetext{
${ }^{1}$ A. Kołdyński, K. J. Zarębski, red. Marcin Siwiec, Belsko-Biała 2008, p. 239.
} 
According to the above quotation, Jane Austen was a very careful observer. She wrote about things she knew and understood - which was very well covered in the following quotation:

'The work of Jane Austen is a phenomenon. It makes no reference to political events - and yet, there were many, beginning with the French Revolution. But - as a stated by literary historian, George Sampson - she wrote about the life she knew and never tried to write about what hasn't been known to her. She had a natural talent for comical. ${ }^{2}$

In the 80s the first sketches of Elinor and Marianne, First impressions and Susan have been made. They all were published, but today we know them in sequence - as: Sense and Sensibility, Pride and Prejudice and Northanger Abbey.

Sense and Sensibility was the first novel published by Jane Austen. The keynote of this novel is the contrast between extremely different characters of two sisters: prudent Eleanor and romantic Marianne. In the eighteenth century there was a tradition of building a novel on the theme of a clash of two opposites; but most often contrasting two features - one which was good and the other evil. Austen, however, goes beyond this tradition by selecting features that aren't excluded. She decided to show compatibility of them. In her opinion, prudence and romance should characterize disposition of each individual, because only their coexistence can guarantee happiness.

Later, in 1813, Pride and Prejudice, has been published. The story takes place in the eighteenth-century realities. Its main character - Elizabeth Bennet is an intelligent young woman. She has four sisters - Jane, Lydia, Mary and Kitty. These four believe in the words of their mother, claiming that only marriage will be fulfillment of their dreams. Elizabeth, however, is different and she wants from life something more than a rich husband who will give her comfortable life in abundance.

When Mr. Bingley - a handsome and rich young man - moves into neighborhood, Elizabeth meets him and his best friend, Mr. Darcy. Mr. Darcy is a man who - at first glance - gives an impression of a very repulsive man. He tries to show that everything bores him, but eventually he starts to consider Elizabeth as an interesting person.

Pride and Prejudice is written in a convention of romance, but it is considered as an one of the first novel of manners. As it was mentioned earlier, the original title of that novel was First Impressions and this refers to Austen's claim that the first impression of knowing someone is often misleading. Only a closer acquaintance will allow someone to change his opinion.

\footnotetext{
${ }^{2}$ A. Kołdyński, K. J. Zarębski, red. Marcin Siwiec, Belsko-Biała 2008, p. 239.
} 
Pride and Prejudice is an example of women's literature - not only because it openly strives to make women aware of their potential, social and political rights. Pride and Prejudice proved to be an inspiration for women who wanted to follow her footsteps when women's literature was beginning to be accepted positively. Despite two centuries since the publication of Pride and Prejudice, we still can find novels inspired by Jane Austen's work. An ideal example is Bridget Jones Diary, published by Helen Fielding in 1996, in which appears even Mr. Darcy.

\section{Semiotic codes in the novel}

It is much easier to interpret semiotic codes in films than in fiction, namely in novels because of their variety. In film adaptations it is possible to find a wide range of audio-visual codes; to find the meaning of facial expressions, gestures, speech and way of moving - as well as signs characteristic for films such as, for example, close-ups. In a novel there is only one system of signs, namely a written language, what makes it difficult to find the individual semiotic codes. However, this is not impossible - it turns out that the filmmaker's work isn't as easy as one would expect.

Interestingly, in a literary text we will not find typical cinematic codes, but we can find the meaning of dress codes, colour codes, class codes and cultural codes.

In the novel it is difficult to analyse individual dress codes, because the narrator rarely attaches importance to the description of clothing, focusing on the presentation of more important things - such as descriptions of events, dialogues or emotions and feelings of characters. Nevertheless, in the Pride and Prejudice we can find some references to the officer uniforms.

When reading the novel we can see how important it is for mothers to find their daughters wealthy husbands. It's enough to mention the moment when Mrs. Bennet learned about the arrival of Mr. Darcy and Mr. Bingley. When it turned out that both men were unmarried, the next thing that caught her attention was their income - five thousand of Mr. Bingley and ten thousand of Mr. Darcy.

That's the reason why the attitude to money is so important. Jane Austen described it as follows:

'They could talk of nothing but officers; and Mr. Bingley's large fortune, the mention of which gave animation to their mother, was worthless in their eyes when opposed to the regimentals of an ensign.'

In the above quotation it is possible to see the meaning of officer's uniform, which misses raised even over assets of potential husband. Having a fortune was important for some of the young women in the novel, but the information about their possessions faded when being compared to the status of 
officers. This means that more honour was given to the officer's wives than to women who were richly married.

'To Catherine and Lydia, neither the letter nor its writer were in any degree interesting. It was next to impossible that their cousin should come in a scarlet coat, and it was now some weeks since they had received pleasure from the society of a man in any other colour.'

For abovementioned ladies a uniform was of great importance. Scarlet was the colour of officers, so every tint of this colour reminded them of their new friends. So why scarlet? Positive connotations of red are those that symbolize love (red roses or red hearts) and passion (hot feelings = flame). Scarlet also symbolizes vitality, life and beauty. Red itself also symbolizes many character features, such as extrovertism, courage, assertiveness, determination and sensitivity. These features are characteristic for a good husband, but also - if we consider courage and determination - characterize a good officer.

With regard to women, there was little connection with their dress. One of the most important dress codes is the moment when Elizabeth came to visit Mr. Bingley's house when her oldest sister became ill. The dress was dirty from mud, what Miss Caroline Bingley noticed. During conversation with Mr. Darcy, she criticized Miss Bennet by calling her a savage; this suggests that women in the lower spheres may behave this way, but she - as a representative of a higher social class - would never let anyone see her in such an attire. It would bring her inexpressible shame.

In the novel we can also find some examples of non-verbal codes. It's difficult to find them, although they exist in a narrative and - much less - in the statements of individual characters. Mr. Collins, describing Lady Catherine, expresses herself as follows:

' (...) he had never in his life witnessed such behaviour in a person of rank-such affability and condescension, as he had himself experienced from Lady Catherine.'

This statement suggests that affordability and politeness are characteristic for lower birth. People with high social status are characterized mostly by pride. It's uncommon for these people to be approachable and so kind to someone they consider to be worse because of their lower birth. On the other hand, those whose social status isn't so high are not lofty and usually relate favourably to anyone, regardless to their connections or wealth.

One more example is the moment when Mr. Darcy met Mr. Wickham.

'Both changed colours, one looked white, the other red. Mr. Wickham, after a few moments, touched his hat-a salutation which Mr. Darcy just deigned to return.' 
Changing of face colour can suggest many things. In this context, the unexpected pallor of one of the men and unnatural blush on the other's face can suggest strong emotions that torment them. Because of the fragment in which Jane Austen described their courtesy greeting, it can be assumed that both gentlemen don't treat each other with respect. The description of their faces, though so concise, gives us an idea of how strong their reluctance is.

When Elizabeth wanted to dance with Mr. Wickham at the ball, her plans were changed by Mr. Collins who asked her to dance.

'There was no help for it, however. Mr. Wickham's happiness and her own were perforce delayed a little longer, and Mr. Collins's proposal accepted with as good a grace as she could.'

Although Elizabeth didn't have the slightest desire to dance with Mr. Collins, her good manners didn't allow her to refuse. Acceptation of his offer with good look testifies her ability to adopt to the prevailing principles of good manners. There is a saying that sometime you have to smile to a bad game and at this point Elizabeth was a perfect example.

When Elizabeth learned that her youngest sister, Lydia, had escaped with Mr. Wickham, she realized what shame she had brought on Bennet's family. This allowed Elizabeth to ask about how Mr. Bennet had received this message. Jane, who was there when her father learned what Lydia had done, replied:

'I never saw anyone so shocked. He could not speak a word for full ten minutes.'

In the novel we can also find some references to social positions that can be read through the prism of class codes. For example, a fragment when Miss Catherine came to Elizabeth to force her to promise never marry Mr. Darcy. In the lower spheres, as we can see on the example of Mrs. Bennet, it's important to find the right husbands for daughters. On the other hand, in the higher social status this matters are being considered very early, choosing for a daughter a men who will be suitable for her in terms of wealth and connections. Apparently, this is the best visible when Lady Catherine talks about her daughter and Mr. Darcy.

'The engagement between them is of a peculiar kind. From their infancy, they have been intended for each other. It was the favourite wish of his mother, as well as of hers. While in their cradles, we planned the union: and now, at the moment when the wishes of both sisters would be accomplished in their marriage, to be prevented by a young woman of inferior birth, of no importance in the world, and wholly unallied to the family!'

Another example of class code is a fragment when Jane was judged by Mr. Bingley's sisters. Eventually she was qualified as a suitable for Mr. Bingley's wife. But what does it matter for him alone? Jane Austen tried to make a clear statement about the role played by Mr. Bingley’s sisters. 
'Miss Bennet was therefore established as a sweet girl, and their brother felt authorized by such commendation to think of her as he chose.'

One more example is the fragment when Lady Catherine invited Mr. and Mrs. Collins and Elizabeth. Mr. Collins said then to Miss Bennet:

"Do not make yourself uneasy, my dear cousin, about your apparel. Lady Catherine is far from requiring that elegance of dress in us which becomes herself and her daughter. I would advise you merely to put on whatever of your clothes is superior to the rest-there is no occasion for anything more. Lady Catherine will not think the worse of you for being simply dressed. She likes to have the distinction of rank preserved."

In the above quotation you can see clearly how much Lady Catherine likes to highlight differences between higher and lower spheres. Regardless of what Elizabeth wear, she would have been considered as worse because of her low birth. In this fragment we can also see the dress code, because the statement that Lady Catherine and her daughter are supposed to be refined may imply that each class of society is fitting a completely different kind of clothing.

'The situation of your mother's family, though objectionable, was nothing in comparison to that total want of propriety so frequently, so almost uniformly betrayed by herself, by your three younger sisters, and occasionally even by your father.'

Above quotation comes from the letter that Mr. Darcy wrote to Elizabeth shortly after she rejected his first proposal. It refers to the low position of Mrs. Bennet's family. This isn't his biggest problem; the low position doesn't empower her to behave in a way that Mrs. Bennet acts. Three of her daughters inherited her approach and this, in turn, is unacceptable for Mr. Darcy. Even Mr. Bennet has been accused of lack of proper approach, although as a head of family he should behave in a more appropriate way even though his family doesn't belong to high class.

Like in many other novels, in Pride and Prejudice we can find many references to cultural codes. Dancing, for example, is popular in every social class, although their forms often differ from one another. The way Miss Caroline Bingley talks about dance - in response to the words of sir Williams - speaks for itself of how popular it is in every social class.

"What a charming amusement for young people this is, Mr. Darcy! There is nothing like dancing after all. I consider it as one of the first refinements of polished society."

"Certainly, sir; and it has the advantage also of being in vogue amongst the less polished societies of the world. Every savage can dance."

Another example of cultural code in this novel is inheritance. The whole of the work is related to the fact that Bennet's estate - after Mr. Bennet's 
death - will be completely rewritten on Mr. Collins because Mr. Bennet has no son; only five daughters.

Inheritance in a male line was widespread in the days of Jane Austen's life. In the absence of a son, the widow and her daughters - if left unmarried have no right to the estate. This is reflected in the following fragment describing Mr. Bennet's approach to his own property and subsequent financial security.

'When first Mr. Bennet had married, economy was held to be perfectly useless, for, of course, they were to have a son. The son was to join in cutting off the entail, as soon as he should be of age, and the widow and younger children would by that means be provided for. Five daughters successively entered the world, but yet the son was to come; and Mrs. Bennet, for many years after Lydia's birth, had been certain that he would.'

Austen's novel has variously been described as politically conservative and progressive. For example, one strand of criticism claims that her heroines support the existing social structure through their dedication to duty and sacrifice of their personal desires. Another argues that Austen is sceptical of the paternalistic ruling "other", evidenced by her ironic tone. Within her exploration of the political issues surrounding the gentry, Austen addresses issues relating to money and property, particularly the arbitrary quality of property inheritance and the precarious economic position of women. Throughout her work there is a tension between the claims of society and the claims of the individual. Austen is often considered one of the originators of the modern, interiorized novel character.

\section{General features of Joe Wright's film adaptation of Jane Austen's novel "Pride and Prejudice"}

Joseph 'Joe' Wright is an English director. He was born in 1972 in London. He started his career in a puppet theatre run by his parents. Then, he spent a year at Camberwell College of Arts. Eventually he earned his education at Central St. Martins University. At the end of his studies he won a scholarship - by making a short film for BBC, which won several awards. It's an interesting thing that he succeeded despite being dyslexic.

Joe Wright himself describes his dyslexic in the following way:

'I think my dyslexia was a vital part of my development, because my inability to read and write meant that I had to find knowledge elsewhere so I looked to the cinema.'

In the nineties he worked in the music label. He also performed many functions during film productions. Later, he worked part-time for Vegetable Vision - a company making music clips.

Joe Wright has been the director of many films since 1997, when Crocodile snap appeared. He also directed a few films, for example: The End, 
Nature Boy, Bob \& Rose, Bodily Harm, Charles II: The Power and The Passion, Pride and Prejudice, Atonement, The Soloist, Hanna, Anna Karenina, Pan, Black Mirror and Darkest Hour.

Joe Wright has received eight awards and numerous nominations. The most important of his nominations was the one in 2008 for the Golden Globe for Best Director. Despite numerous nominations for the BAFTA Awards, he won only two of them: for the Most Promising Newcomer (for Pride and Prejudice) and for Best Drama Serial (for Charles II: The Power \& The Passion). He also won several other awards and received several nominations. Among other things - thanks to the Boston Society of Film Critics award for Best New Filmmaker - it can be said that his career, despite the adversities associated with dyslexia, turned out to be satisfactory.

Despite the fact that Joe Wright directed many films, his greatest successes have been three productions.

The first one is the film Penance, directed in 2007, in which a thirteenyear-old Briony Tallis is watching a love scene between her sister and their servant's son. Incorrect interpretation of this event will lead to tragedy. This film won many awards. First of all, it had seven nominations to OSCAR, eventually winning the award for best original music by Dario Marianelli. That film also received seven nominations for Golden Globe, winning two of them: Best Music and Best Drama. It also received many other less important awards.

Joe Wright's second success was the film Hanna, which was directed in 2011. The film tells the story of a sixteen-year-old, Hanna, who has been trained to be a killer since she was a kid. Now she has to face special agents. This film received much less awards than Penance, but it marked its place in the world of filmmaking, earning the IFTA Award for Best Actress and receiving nominations for many other awards.

The third - undoubtedly the most important for his work - success of Joe Wright, was Pride and Prejudice, directed in 2005. The film received twenty one nominations, including four wins: Best Actress (Keira Knightley), Best Original Music (Dario Marianelli), Best Stage Design and Best Costume. It also received two nominations for Golden Globe - for Best Comedy or Musical and for Best Actress in a Comedy or Musical. Among many nominations for less prestigious awards, Pride and Prejudice won the BAFTA Award for Best British Director, Screenwriter or Producer for his debut film (Joe Wright). It also won Satellite Awards for Best Costumes and the Award of Boston Society of Film Critics for Best Filmmaker, Joe Wright.

Although Joe Wright's adaptation was made in 2005, he managed to reflect Austen's insights. What is more, he did his best to show the specific historical period - costumes, the manner of speaking and behaviour. Wright also managed to show different classes in that society, focusing on showing 
what happens when a girl of a lower birth falls in love with a men born in a higher class. In the novel we can see that by the situation of Mr. Bingley and Jane Bennet and - what's shown in a slightly better way - the complicated situation of Mr. Darcy and Elizabeth. It can be clearly seen when Mr. Darcy tells Elizabeth about the reason why he shouldn't marry her. In that adaptation every part of this scene is shown in a very good way.

In the Internet it is possible to find different opinions about Pride and Prejudice directed by Joe Wright. One of them is presented below.

'I have to say that there is an advantage to the length of a feature film. When I want a little dose of P\&P, this is the version I usually reach for. A miniseries is a time commitment which used to find easier than I do know. This is my best-sized version. I also love the 'muddy hems' and more realistic late $18^{\text {th }}$ century setting and costumes. Gorgeously filmed and the music is lovely. (...) The only thing that really bugs me about this version is the way the first proposal (in the rain in this version) is so rushed. I know they were trying to make it as though it was rehearsed and rushed but it just comes off kind of crazy.'

\subsection{Semiotic interpretation of Joe Wright's interpretation the analysed novel}

Semiotic codes division mentioned above has proved to be helpful in analysing semiotic codes in Joe Wright's interpretation.

Joe Wright outlined differences in the manner of dress, modelling on generally accepted standards at the time of writing novel. It is most visible when sisters Bennet and their mother go to visit Jane, who is staying at Mr. Bingley's estate.

Miss Carline Bingley was dressed in an elegant dress in subdued colours. To this day, it is assumed that the attire in toned colours, simple and devoid of unnecessary designs are a symbol of elegance. Miss Carline's long dress made the woman emanated with elegance, emphasizing her social position. In turn, the Bennet family was dressed in patterned, colourful dresses. This is mainly due to their social position and lack of wealth. Elegance is expensive, so Miss Caroline didn't have a good opinion about them. She didn't respect people representing lower classes.

The second manifestation of dress code was to show Mr. Wickham in a uniform. The man in each scene is wearing a military uniform. To this day, wearing a uniform raises respect for the person who wears it. He is instinctively respected, which - in the case of Mr. Wickham - is rather a kind of irony, a specific message of Austen's specific humour.

The most important colour code is the manner in which misses was presented on the ball that Mr. Bingley organised. All of them were dressed in different types of dresses, but each one was either white or light. 
The symbolism of the white colour points to purity. The appearance on balls was conducive to find the right husband. That is why each of girls showed up in white, wanting to show their unmarried status at once.

The language of film is also called a system of audio-visual signs. This means that in every kind of adaptation we can see non-verbal codes at every step. Each scene shows the manner of speaking of actors, their facial expressions and gesticulation. Showing body language is inevitable in every film. Also in the interpretation of Joe Wright it is possible to find meanings hidden in even smallest gestures.

When Mr. Bingley returned from London, he and Mr. Darcy visited the house of Bennet's family. Mr. Bingley was tense. The unnatural stance, the dashing eyes and the expression of his face reflected his feeling. On the other hand, in the next scene, in which Mr. Bingley and Mr. Darcy are talking alone, Mr. Bingley was behaving quite differently. He couldn't stand in one place, going back and forth what showed that he is very upset, very exited. Unusual for him very lively gesticulation testifies to his nervousness and anxiety. He talks about meeting Jane and he's desire for marriage. It is clear that's the reason for his untypical behaviour.

The scene where Mr. Darcy nearly runs into the room where Jane is, also perfectly shows how much body language is significant to interpret intentions and attitudes of the character played by the actor. Mr. Darcy, standing in front of Elizabeth, holds gloves in his hands, nervously pinching them by his fingers. This is one of a few moments in Wright's interpretation when Mr. Darcy stops being so self-controlled. He makes the impression of a deeply moved man, because he's unable to state the reason of his arrival, although his gestures indicate that he has made many attempts. His dashing eyes are also a sign of nervousness. Mr. Darcy nearly ran out of the room, showing that - if he was deeply moved - he couldn't hide his emotions as he did almost all the time. The reason for such behaviour is shown only a moment later when - in a completely different situation - he confesses his feelings to Elizabeth.

When Jane returned from her uncle in London, she said to Elizabeth that she's not interested in Mr. Bingley at all anymore. She states that she will find someone more suitable for her, but her expression contradicts every word. It is hard to see any emotions on her face - which is characteristic for this character - but all her posture shows sadness. Close-up of the camera on her face shows the emotions visible in her eyes. Sorrow, longing and sadness are just a small part of her feelings. Her quiet tone of voice suggest that she's telling the truth. A more insightful observer will notice that the voice washed out of all emotions is merely an attempt to hide her real feelings and emotions.

Racial codes aren't displayed in the interpretation at all, because of their total absence in the original. 
Class codes are the next group of codes that we can find in Joe Wright's interpretation.

A vivid example is when Mr. and Mrs. Bennet are talking about Mr. Bingley. This scene is shown at the very beginning of the film when Mrs. Bennet tries to persuade her husband to visit Mr. Bingley. The desire is shown due to the fact that Mrs. Bennet is keen on the best way to marry all of her five daughters. She is excited and will do anything to make her husband adjust to her requests.

Throughout this interpretation it is being noted that Mrs. Bennet's only desire is to have her daughters well married - especially because of lack of proper education of them and the lack of wealth. A good comparison may be Lady Catherine, who thinks that Mr. Darcy is the best candidate for her son-inlaw. She is sure that Mr. Darcy choose a woman of high social status and wealth. It perfectly shows the difference between classes.

The second example of revealing class codes is when Lady Catherine visits Bennet's house late at night. She informs Elizabeth that her daughter is engaged to Mr. Darcy and straightforwardly says that there is no way that Mr. Darcy would propose Elizabeth - because of all above-mentioned things.

Namely, Elizabeth is socially too inadequate, has no proper education, can't play any instrument and draw. What is more, her family is considered as an inadequate. Lady Catherine insulted Elizabeth in a every possible way, showing her differences between her and Lady Catherine's daughter and she gave Miss Bennet the impression that she considered her worse in every aspect. It all comes down to Elizabeth's lack of wealth and - consequently her social position. In Lady Catherine's eyes Miss Bennet was, is and always will be much worse choice for a man than a high-born woman of proper education and wealth.

The next example of class code is quite funny. In one scene we can see two servants standing nearby when Mr. Caroline, Mr. Bingley and Mr. Darcy are eating their meal. In the second scene, in contrast, we can see a pig running through the Bennet's house. Joe Wright in a very contradictory and funny way presented the differences between that two classes.

One of the most obvious examples of cultural codes that can be found in Joe Wright's interpretation is the first ball shown in the film. By showing both dancing couples and people sitting near and having a conversation with each other, Joe Wright wanted to show one of the main goals of making balls namely, acquiring new friendships.

Likewise, the essence of church is shown when pastor - Mr. Collins leads the sermon. It should be noted first that all pastors enjoys great respect among other people. Respect for such a person is expressed by listening to their sermons in silence and in full concentration. 
Movies themselves have their own codes. They are inseparable from them and can't be found in literary, theatrical or comic works. Once with the advancement of technology, more and more opportunities are emerging.

It is best visible during the first dance of Elizabeth and Mr. Darcy. Frist, they're shown among all other dancing couples. The description of what was done by Joe Wright won't give his full intentions or how it was like watching a movie. At one point, all the people disappeared from the frame and only Mr. Darcy and Elizabeth remained. Wright showed in this way how important their first meeting is for the whole story. He also exaggerated the meaning of that dance for both of them. Proud Mr. Darcy, who avoids dancing whenever it is possible, tempts to dance with Elizabeth - a woman whose social position and amount of her possessions are lower than his own. Thanks to this we can see that Mr. Darcy had to be charmed by Elizabeth at the very beginning, even though he didn't consider her at first as attractive.

The second effect which was achieved by Joe Wright, is the analysis of the scene of Mr. Darcy's first proposal. The quarrel between him and Elizabeth is filled with emotions and audio-visual signs, namely a scene which can't be fully expressed in literary text. Their behaviour, full of gestures and faces filled with emotions - although not very positive - indicate the full of passion quarrel of two people who cares about each other but they don't want to show it. At one point Elizabeth accused Mr. Darcy of everything what made her be repulsive to him. He didn't respond - maybe he just didn't want to comment some things.

So he stopped talking, taking a step toward Elizabeth. None of them tells a word and the camera turned on their faces. Although Elizabeth's face was filled with anger and resentment, Mr. Darcy's face was like a mask - empty and indifferent. With the close-up on their faces, it was clear that Mr. Darcy was beating his mind while closing his face toward Elizabeth's. The recipient feels that he wants to kiss her but - looking at her disapproving expression he changes his mind, apologizes for taking her time and leaves the room.

A similar situation was made by Joe Wright during Mr. Darcy's second proposal, this time willingly accepted. When Elizabeth goes for a walk, her eyes catch a lonely figure walking in the light of the rising sun. The camera moves on Mr. Darcy. In the background we can hear music, original and romantic.

What did Joe Wright want to achieve though such operation? Wright decided to leave it to the recipient's interpretation. Nevertheless, it may suggest that Mr. Darcy, despite all previously encountered adversities, goes back to Elizabeth to confess his feeling for her once more. Music suggests his hope and the rising sun symbolizes a new beginning. That's exactly what happened. 


\subsection{Joe Wright's adaptation through the prism of intersemiotic translation}

When comparing literary text with its film adaptation, it is necessary to recall intersemiotic translation as a key method of this comparison. Roman Jakobson states that it is a translation from one linguistic system to another which means the transference of meaning from a verbal to a non-verbal system. In the further part of the article, there will compare the selected four scenes taken from the adaptation and the source text.

\section{Mr. Collin's proposal}

In the film adaptation, during the meal, Mr. Collins asked for permission to have a private conversation with Elizabeth. Her reaction when she heard his question was quite well shown in the film adaptation. Knowing that she couldn't win with her mother, she turned to Jane, but she only smiled and left the room. Looking for a last resort, Elizabeth looked directly at Mr. Bennet. She did it with a silent pleading visible in her eyes and across her facial expression, waiting for his reaction. Despite she really didn't want to be left alone with Mr. Collins, her family left the room.

In the novel, Jane Austen showed Elizabeth's emotions in the following way:

"Dear ma'am, do not go. I beg you will not go. Mr. Collins must excuse me. He can have nothing to say to me that anybody need not to hear. I am going away myself."

Jane Austen also writes that Elizabeth's seeming really, with vexed and embarrassed looks, about to escape.

Mr. Collins started the conversation by saying that his behaviour is too clear to be mistaken. Calmly, almost not revealing any feelings, he said that he wishes to present reasons why these two should get married. Wright decided not to show any emotions of Mr. Collins who therefore was giving the impression of a bored man. His voice suggested lack of interest in discussing the rational reason why he should marry Elizabeth. He didn't seem interested, not to mention in love. Mr. Collins noted that - since he was to inherit property - such a relationship would be good to all of them. By this words, he suggested that Elizabeth might be more interested in his property than in himself. Mr. Collins said that he wants to express how violent is his feeling, but - judging by his expression - he looked bored. He also added that he will never object Miss Bennet lack of assets. The way he said that suggested the absence of any romantic feelings for Elizabeth and lack of respect towards her.

Throughout this conversation, the most characteristic thing that strikes the eye is the lack of eye contact. It's always been a sign for insincerity. 
In the novel, the beginning of this scene is almost the same. Mr. Collins presented reasons why they should get married. Then he's trying to prove violence of his feelings, which Austen describes in the following way:

'The idea of Mr. Collins, with all his solemn composure, being run away with by his feelings, made Elizabeth so near laughing (...)'

Austen focuses mainly on the presentation of the conversation itself, allowing the reader to assess. However, she showed the true face of Mr. Collins. When he heard a negative response to the proposal, he replied with a formal wave of the hand. Jane Austen used a minimum amount of words to describe Mr. Collins' character. A reflection of that in the film was avoiding Elizabeth's gaze and the voice devoid of any emotions.

\section{The appearance of Mr. Bingley and Mr. Darcy}

Joe Wright focused on the relatively spectacular presentation of Mr. Darcy, Mr. Bingley and Miss Caroline.

In the film adaptation we first see Mr. Bingley when he appears at the ball in the company of his sister, Caroline, and Mr. Darcy. Gathered at the ball people had enjoyed themselves and danced when the door opened and Mr. Darcy, Mr. Bingley and Miss Caroline were shown. The director showed how everyone suddenly froze. The music stopped playing - in this way Wright showed the importance of this scene. There is a tendency in films to create similar scenes to enhance an event. Thanks to that it can be felt that all gathered people awaited with curiosity to their arrival. They have been coming out of their way when they walked through the ballroom, proud and haughty. This way people gathered at the ball confirmed guest's belief that they are very important figures.

Mr. Darcy, Mr. Bingley and his sister walked slowly, scanning the surroundings with superior and people worshiped when they were passing by. When the trio arrived to their sets, the ball resumed almost immediately.

In the scene introducing these characters for the first time, we can observe a clear difference between the film and the novel.

In the novel, Mr. Bingley appears in the ballroom in the company of his two sisters and husband one of them. There is also his best friend, Mr. Darcy.

Jane Austen showed them in slightly different way. She focused on description of Mr. Darcy and Mr. Bingley in a way showing differences between them and presenting their characters in the literal way. The reader can see that by following:

'Mr. Bingley was good-looking and gentlemanlike; he had a pleasant countenance, and easy, unaffected manners. (...)

In turn, Mr. Darcy was shown as his opposite.

'The gentlemen pronounced him to be a fine figure of a man, the ladies declared he was much handsomer than Mr. Bingley, and he was looked at with great admiration for about half the evening, till his manners gave a disgust 
which turned the tide of his popularity; for he was discovered to be proud, to be above his company, and above being pleased; and not all his large estate in Derbyshire could then save him from having a most forbidding, disagreeable countenance, and being unworthy to be compared with his friend.

Mr. Bingley had soon made himself acquainted with all the principal people in the room; he was lively and unreserved, danced every dance, was angry that the ball closed so early, and talked of giving one himself at Netherfield. Such amiable qualities must speak for themselves. What a contrast between him and his friend!'

Austen tried to enter the characters with appropriate efficiency. She showed the type of characters we have to deal with.

We can safely say that Joe Wright managed to present the main characters while adopting this scene.

\section{Presentation of Mr. Wickham}

In the novel, Elizabeth noticed the reaction of Mr. Darcy and Mr. Wickham when they look at each other.

Mr. Wickham has been presented in the uniform. This had been done on purpose to show his devotion to work. The appearance of the uniform with the principle compels respect for the person who wears it. Austen was aware of this, deliberately showing this character as respected and trust worthy citizen. Joe Wright noticed that and tried to reflect Austen's intentions in the best possible way.

During the film scene where we first saw Mr. Darcy and Mr. Wickham together, we could observe an intriguing behavioural process. Mr. Wickham was standing in the unnaturally upright position. He has a fierce expression on his face and almost a lust of murder in his eyes. He was looking directly at Mr. Darcy, never taking his eyes away from him. He stopped acting this way after Mr. Darcy's leaving. Darcy, however, reacted on Mr. Wickham in the same way.

Jane Austen shows their meeting in the following way:

'Mr. Darcy corroborated it with a bow, and was beginning to determine not to fix his eyes on Elizabeth, when they were suddenly arrested by the sight of a stranger, and Elizabeth happening to see the countenance of both as they looked at each other, was all astonishment at the effect of the meeting. Both changed colour, one looked white, the other red. Mr. Wickham, after a few moments, touched his hat - a salutation which Mr. Darcy just deigned to return.'

This scene in the film adaptation differs from that described by Austen. The faces of men hadn't changed colour, but Joe Wright found an adequate way to show their mutual dislike - by unnaturally upright positions, for example. He also managed to show Elizabeth intrigued expression when she was looking at Mr. Darcy. Then, Miss Bennet turned her gaze to Mr. Wickham's face in order to determine his reaction to this meeting. 
Joe Wright, even he didn't reflect this meeting a hundred percent alike, managed to show the depth of this scene exactly in the way as it should be shown.

\section{Meeting with Lady Catherine}

Elizabeth received an invitation to dinner at Rosings - place owned by Lady Catherine. During this dinner, Elizabeth was flooded with questions from Lady Catherine. Miss Bennet considered them as somewhat inappropriate, but she answered politely an patiently on every one of them. However, some of her answers were considered by Lady Catherine as impertinent.

The film adaptation as well as the adapted material highlighted a specific character of Miss Bennet. Authors have shown that - without worrying about all standards for a women in her age - she has her own opinions and she's not afraid to express them. Even if they clashes with the views of older, well respected women.

This scene, both in the novel and in the film adaptation, shows in a very clear way the character of Elizabeth and Lady Catherine. In the film Lady Catherine asks questions about Miss Bennet's education. In that way she suggest a lack of proper education of young ladies Bennet. Question are being asked in a tone full of superiority, implying that Elizabeth is considered by Lady Catherine as a worse than others. Characteristically raised eyebrow suggest surprise, though rather as the reaction of Elizabeth's bold responses than to her upbringing. words:

Jane Austen in a perfect way describes Lady Catherine, using only a few

' (...) delivering her opinion on every subject in so decisive manner, as proved that she was not used to have their judgement controverted.'

Elizabeth listened calmly to all insults disguised in a polite questions, answering seemingly politely and patiently. The more questions, the more Miss Bennet was losing her patience. When being asked whether her sisters are already in the company, she replied:

' (...) But really, ma'am, I think it would be very hard upon younger sisters, that they should not have their share of society and amusement, because the elder may not have the means or inclination to marry early. The last-born has as good right to the pleasures of youth as the first.' 


\section{REFERENCES}

1. U. Eco. A Theory of Semiotics. Bloomington, IN: Indiana University Press/London: Macmillan, 1976.

2. M. Halliday. Ideas about Language. Reprinted in Volume 3 of MAK Halliday's Collected Works. Edited by J.J. Webster. London: Continuum. P. 113, 1977.

3. F. Saussure. Course in General Linguistics (trans. Roy Harris). London: Duckworth, 1983.

4. A. Jane. Pride and Prejudice, Prószyński i S-ka, Warszawa, 2015.

5. H. Marek. Język ruchomych obrazów, Ars Nova, Poznań, 2014.

\section{Information about the author:} Smagliy V. M., $\mathrm{PhD}$, Assistant Professor, Head of the Philology Department, Odessa National Maritime University 34, Mechnikova str, Odesa, 65029, Ukraine 